\begin{tabular}{|c|c|c|c|}
\hline \multirow{3}{*}{$\begin{array}{r}\text { Case Reports in } \\
\text { Gastroenterology }\end{array}$} & Case Rep Gastroenterol 2 & & \multirow[b]{2}{*}{$\begin{array}{l}\text { Karger } \\
\text { Opengaccess }\end{array}$} \\
\hline & $\begin{array}{l}\text { DOI: 10.1159/000468509 } \\
\text { Published onlIne: AprII 10, } 2017\end{array}$ & $\begin{array}{l}\text { (c) } 2017 \text { The Author(s) } \\
\text { Published by S. Karger AG, Basel } \\
\text { www.karger.com/crg }\end{array}$ & \\
\hline & $\begin{array}{l}\text { This article is licensed under } \\
\text { International License (CC BY-N } \\
\text { Usage and distribution for comm }\end{array}$ & $\begin{array}{l}\text { nons Attribution-NonCommercial } 4.0 \\
\text { ger.com/Services/OpenAccessLicense) } \\
\text { uires written permission. }\end{array}$ & \\
\hline
\end{tabular}

\title{
Successful Endoscopic Management of Late Biliary Cast Syndrome in a Liver Transplant Recipient: A Case Report
}

\author{
Manuel Alejandro Mahler ${ }^{a}$ Federico Marcaccio ${ }^{a}$ \\ Jean-Marc Dumonceau ${ }^{b}$ Carlos Macías Gómez ${ }^{a}$ \\ ${ }^{a}$ Gastroenterology Service, Hospital Italiano de Buenos Aires, Buenos Aires, Argentina; \\ ${ }^{\mathrm{b}}$ Gedyt Endoscopy Center, Buenos Aires, Argentina
}

\section{Keywords}

Liver transplant - Endoscopic retrograde cholangiopancreatography · Biliary cast syndrome . Sphincterotomy

\begin{abstract}
Biliary cast syndrome (BCS) is an unusual complication of liver transplantation (LT). The pathophysiology is not known, and it is thought to develop because of mucosal damage in the bile duct related to obstruction, ischemia, or bacterial infection. It occurs in $2.5-18 \%$ of LT patients and is associated with increased graft failure, need for retransplantation, and mortality. Here we report on a case of BCS of late appearance after LT who was successfully treated by endoscopic means.

(C) 2017 The Author(s)

Published by S. Karger AG, Basel
\end{abstract}

\section{Introduction}

Biliary cast syndrome (BCS) was first described in 1975 and refers to the presence of multiple hard pigmented dark materials that mold the bile ducts. BCS is reported to occur in $2.5-18 \%$ of patients with liver transplantation (LT) [1, 2] and much less frequently in nonLT settings, including postoperative status, fasting associated with total parenteral nutrition, 


\section{Case Reports in Gastroenterology}

Case Rep Gastroenterol 2017;11:207-211 DOI: $10.1159 / 000468509$

c 2017 The Author(s). Published by S. Karger AG, Basel www.karger.com/crg

Mahler et al.: Successful Endoscopic Management of Late Biliary Cast Syndrome in a Liver Transplant Recipient: A Case Report

and gallbladder hypomotility [3-6]. BCS in an LT setting is associated with ischemic injury to the biliary endothelium and strictures. Other mechanisms, such as acute cellular rejection and infection, have been proposed to play an etiological role in the development of BCS. With respect to the timing of cast formation, it has mostly been reported within the first year following LT, and rarely up to 5 years after LT [7].

\section{Case Report}

A 67-year-old male with a history of LT 6 years earlier for hepatitis B-induced cirrhosis presented at the emergency room with epigastric pain irradiating into the right upper quadrant. Physical examination revealed tenderness in the upper abdomen and no other abnormality. Routine laboratory evaluation only revealed a slight elevation in gamma-glutamyl transferase at $71 \mathrm{IU} / \mathrm{L}$ (reference range, 9-51 IU/L), with normal alkaline phosphatases, aminotransferases, bilirubin, and prothrombin time. Abdominal ultrasound disclosed a normal common bile duct diameter with normal portal and hepatic artery Doppler flows. Liver biopsy showed bile duct proliferation, biliary clots, and neutrophilic cholangitis, suggesting cholestasis and no acute rejection. Magnetic resonance cholangiopancreatography revealed a filling defect in the common hepatic and cystic ducts, extending down from the main hepatic confluence to the ampullary level. These findings were consistent with BCS (Fig. 1).

Endoscopic retrograde cholangiopancreatography confirmed the magnetic resonance cholangiopancreatography findings (Fig. 2), and endoscopic therapy was performed. After biliary sphincterotomy, a stone retrieval balloon was passed into the bile duct and positioned below the main hepatic confluence, inflated, and withdrawn distally to extract the cast (Fig. 3). Subsequently, regular saline flushes were employed to facilitate drainage of remainder cast from the cystic duct, and an occlusion cholangiogram allowed to exclude the presence of any anastomotic stricture. The patient's course was uneventful, pain disappeared, and he was discharged $24 \mathrm{~h}$ after admission. He was followed with clinical and imaging controls on a bimonthly basis during the first year and then annually up to 2 years, without any sign or symptom of recurrence.

\section{Discussion}

BCS is an uncommon condition occurring mostly after LT, defined by the presence of casts within the intra- or extrahepatic biliary system. It morphologically appears as dark, hardened material molded to the bile ducts, different from the usual round shape of biliary stones. Although bile duct stones and biliary casts have a similar microstructure $[8,9]$, their mechanism of formation differs significantly. The risk factors for BCS following LT include ischemia-reperfusion injury, prolonged cold preservation, prolonged warm ischemia, and hepatic artery thrombosis [10].

Biochemically, biliary casts consist of bilirubin as the primary component (approximately $10-50 \%)$, followed by bile acid synthesis products and cholesterol $(10-15 \%)$ and protein or collagen from necrotic biliary epithelial cells (5-10\%) [8]. Using choledochoscopy, patients with BCS have been classified into 6 categories according to the level of injury to the biliary tract epithelium [10]. From type 1 to type 6 , clinical symptoms and biliary tract strictures are more frequent and the size of biliary casts increases. In type 1 (intact bile duct epithelium), clinical symptoms or laboratory index changes are absent, while type 6 (necrotic 


\section{Case Reports in Gastroenterology}

Case Rep Gastroenterol 2017;11:207-211 DOI: $10.1159 / 000468509$ (C) 2017 The Author(s). Published by S. Karger AG, Basel www.karger.com/crg

Mahler et al.: Successful Endoscopic Management of Late Biliary Cast Syndrome in a Liver Transplant Recipient: A Case Report

biliary duct epithelium in the common hepatic duct plus left and right hepatic ducts) usually develops early in the postoperative period and frequently requires retransplantation. We believe that the case reported here belongs to type 1 or 2 based on the indolent patient course, including the long delay since LT at presentation, the paucity of symptoms at the time of diagnosis, and the unremarkable patient follow-up for 2 years following endoscopic extraction of the biliary cast. In particular, to our knowledge the delay of 6 years between LT and BCS diagnosis is one of the longest reported in the literature.

\section{Statement of Ethics}

Written informed consent for the procedure was signed by the patient.

\section{Disclosure Statement}

All authors disclose no financial relationships relevant to this publication.

\section{References}

1 Waldram R, Williams R, Calne RY: Bile composition and bile cast formation after transplantation of the liver in man. Transplantation 1975;19:382-397.

-2 Starzl TE, Putnam CW, Hansbrough JF, Porter KA, Reid HA: Biliary complications after liver transplantation with special reference to the biliary cast syndrome and techniques of secondary duct repair. Surgery 1977;81:212-221.

-3 D'Haens GR, Ruchim MA, Goldberg MJ, Baker AL: Massive intra-hepatic and extra-hepatic bile cast formation after cholecystectomy. Gastrointest Endosc 1993;39:579-581.

-4 Byrne MF, Chong HI, O’Donovan D, Sheehan KM, Leader MB, Kay E, McCormick PA, Broe P, Murray FE: Idiopathic cholangiopathy in a biliary cast syndrome necessitating liver transplantation following head trauma. Eur J Gastroenterol Hepatol 2003;15:415-417.

5 Gleeson FC, Czaja AJ, Baron TH: Successful endoscopic management of biliary cast syndrome in nonliver transplant patients. J Clin Gastroenterol 2008;42:752-755.

6 Katsinelos P, Kountouras J, Chatzimavroudis G, Zavos C, Pilpilidis I, Paroutoglou G: Combined endoscopic and ursodeoxycholic acid treatment of biliary cast syndrome in a nontransplant patient. World J Gastroenterol 2008;14:5223-5225.

7 McMaster P, Herbertson BM, Cusick C, Calne RY, Syrakos T, Marni A: The development of biliary "sludge" following liver transplantation. Transplant Proc 1979;11:262-266.

8 Shah JN, Haigh WG, Lee SP, Lucey MR, Brensinger CM, Kochman ML, Long WB, Olthoff K, Shaked A, Ginsberg GG: Biliary casts after orthotopic liver transplantation: clinical factors, treatment, biochemical analysis. Am J Gastroenterol 2003;98:1861-1867.

9 Yu Q, Yang YL, Lin MJ, Zhang HW, Shi LJ: A comparative study of liver transplantation biliary cast and morphology of bile duct stones. Zhonghua Waike Zazhi 2011;49:650-651.

10 Zhu XD, Shen ZY, Chen XG, Zang YJ: Pathotyping and clinical manifestations of biliary cast syndrome in patients after an orthotopic liver transplant. Exp Clin Transplant 2013;11:142-149. 


\section{Case Reports in Gastroenterology}

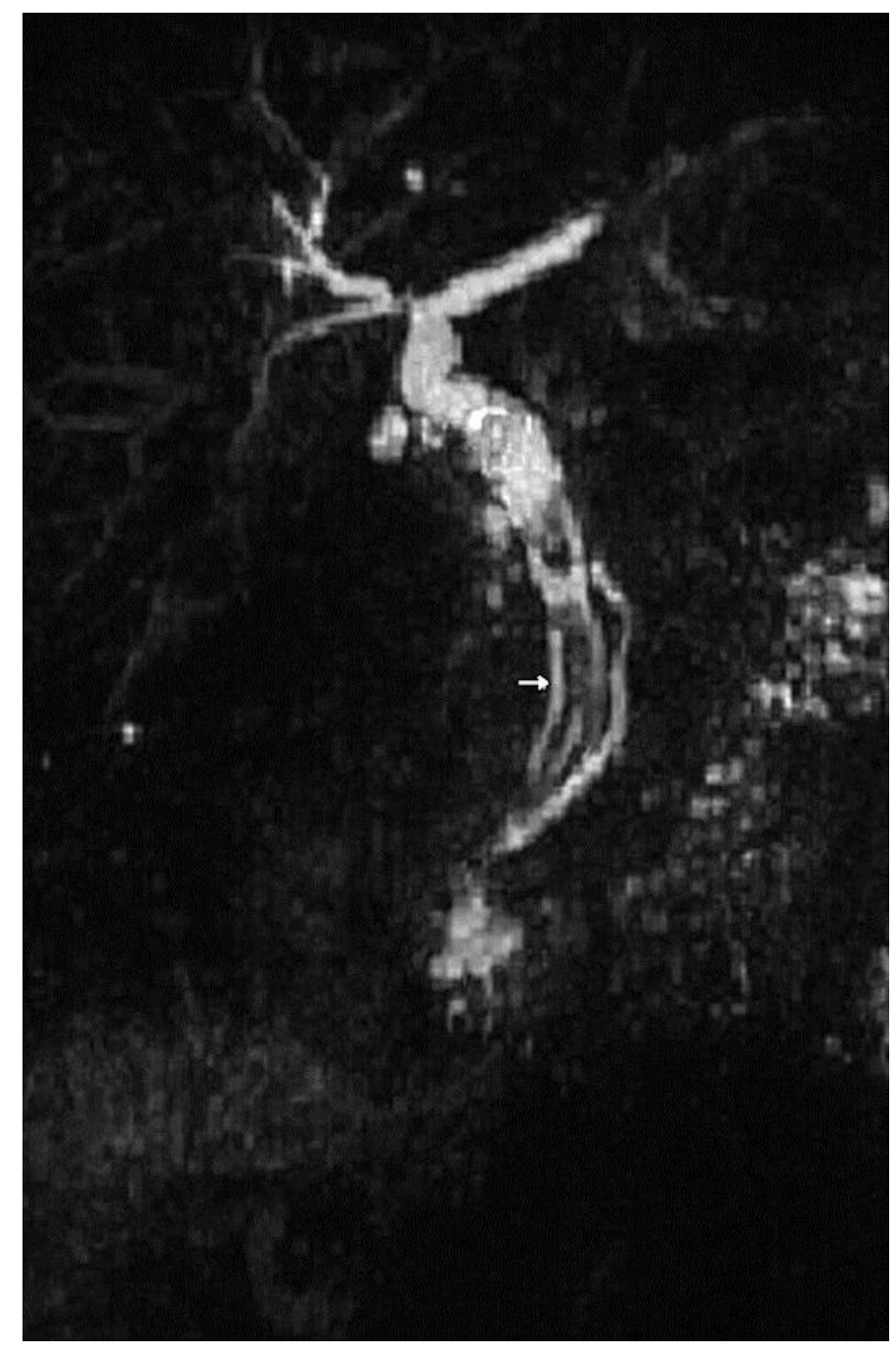

Fig. 1. Magnetic resonance cholangiopancreatography showing a long filling defect (arrow) in the extrahepatic ducts suspicious for biliary cast.

Mahler et al.: Successful Endoscopic Management of Late Biliary Cast Syndrome in a Liver Transplant Recipient: A Case Report 


\section{Case Reports in Gastroenterology}

\begin{tabular}{l|l}
\hline Case Rep Gastroenterol 2017;11:207-211 \\
\hline DOI: 10.1159/000468509 & $\begin{array}{l}\text { C } 2017 \text { The Author(s). Published by S. Karger AG, Basel } \\
\text { www.karger.com/crg }\end{array}$ \\
\hline
\end{tabular}

Mahler et al.: Successful Endoscopic Management of Late Biliary Cast Syndrome in a Liver Transplant Recipient: A Case Report

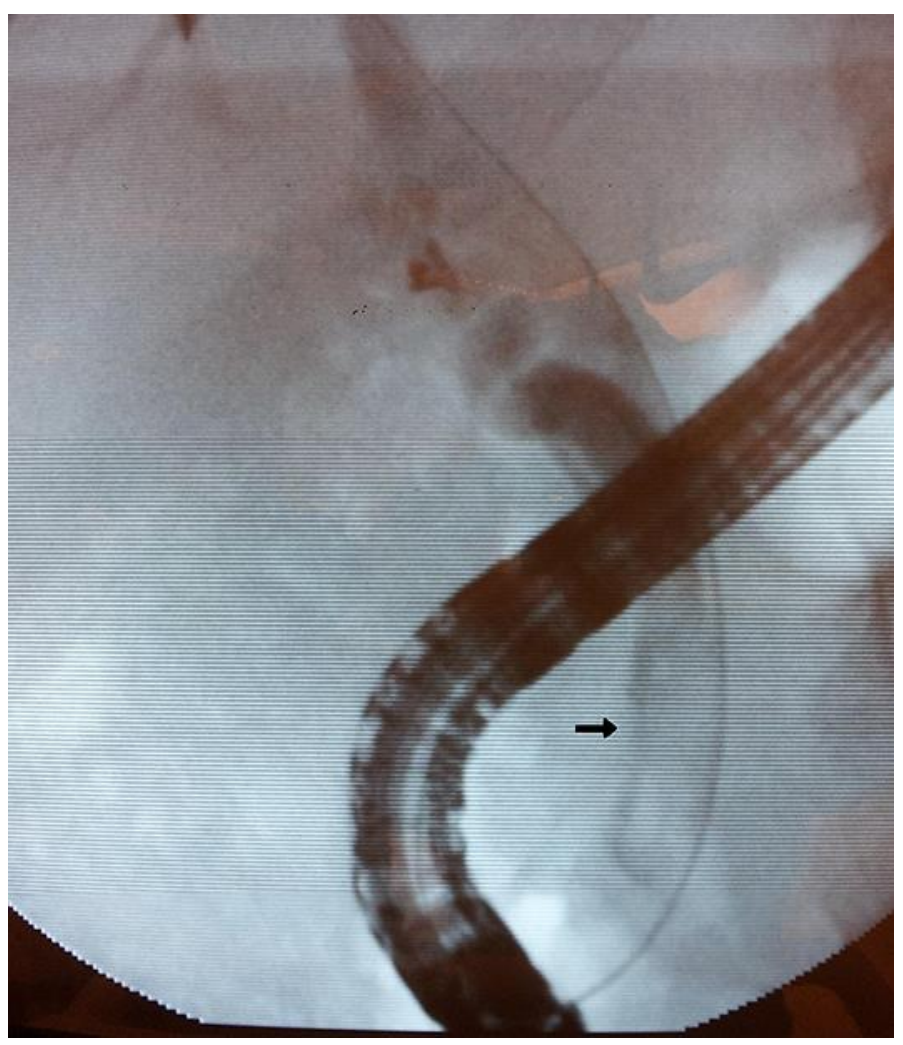

Fig. 2. Endoscopic retrograde cholangiopancreatography confirming the presence of a filling defect (arrow) in the slightly dilated extrahepatic ducts.

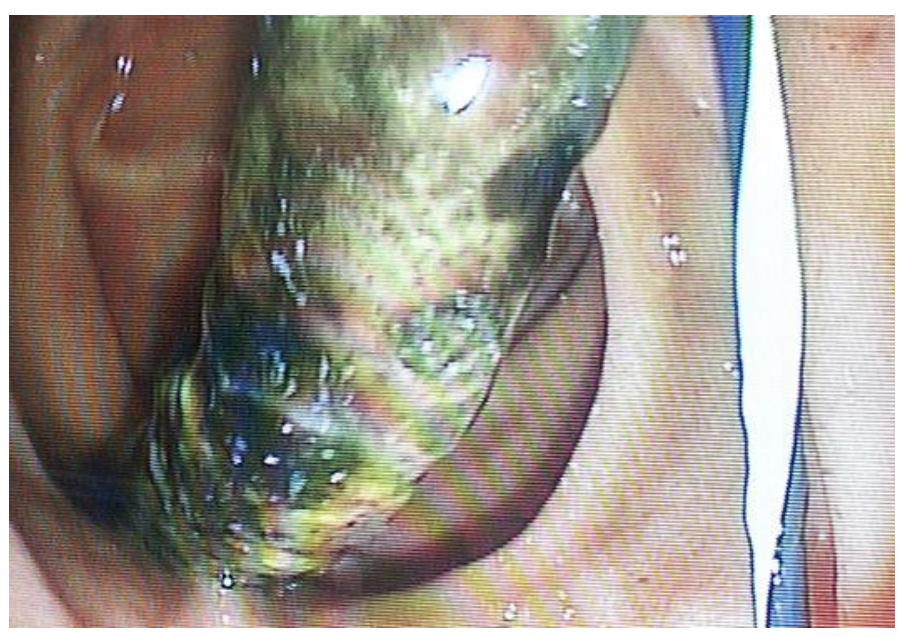

Fig. 3. Endoscopic view of the biliary cast in the duodenum after sphincterotomy and balloon-assisted extraction. 